\title{
The Right to Disturb
}

\author{
Roberto Refinetti ${ }^{1}$
}

Published online: 8 February 2018

(C) Springer Science+Business Media, LLC, part of Springer Nature 2018

In January 2018, one hundred French women published an open letter in the newspaper Le Monde criticizing the late-2017 surge of accusations of sexual misconduct against powerful men in the television and film business (Chiche et al. 2018). The authors, who included actress Catherine Deneuve and writer Catherine Millet, were sympathetic to victims of abuse, but they made their feelings clear that justice is not served by undocumented complaints of an angry mob, as further clarified later by Deneuve (2018).

Such a call for fairness contrasts with an opposite trend in Europe, the United States, and other regions of the world, and it reflects an encouraging move towards reason. Deneuve and the other ninety-nine women argue that men should have the right to "disturb" women by making potentially unwelcome sexual propositions, just as much as women should have the right to disturb men by shutting them off. Prohibiting the free expression of sexual interest, they point out, would curtail sexual freedom.

In the United States, sexual harassment became a crime almost half a century ago, but, although the law is reasonably clear about what constitutes sexual harassment (U.S. Equal Employment Opportunity Office 2018), most people have their own opinion about it. This divergence between the law and popular opinion was the central theme of the very first issue of Sexuality \& Culture, twenty-one years ago (Refinetti 1997). Then, a group of scholars called for common sense in the evaluation of romantic relationships between consenting adults in a university setting. The signatories of the Le Monde letter are likely dealing with an industry (Hollywood film-making) in which power relations are more complex than in academia, but the two scenarios are clearly similar.

Roberto Refinetti

refinetti@circadian.org

1 Department of Psychological Science, Boise State University, Boise, ID 83725, USA 
Let us not miss the central issue: no one denies that even though an aspiring actress might feel that having sex with a powerful male producer is an acceptable way to advance her career, another actress who does not wish to have sex with the producer should not have her path toward stardom blocked by her unwillingness to accept the proposition. It is important to notice also that the fact that most men in positions of power are heterosexual means that aspiring male actors do not even get the chance to exchange sex for career advancement-their path to stardom gets summarily shut off. Powerful men (as well as powerful women) assertively exert power over other people-be they women or men. The signatories of the Le Monde letter are well aware of this. They do not condone sexual harassment-much less sexual violence, which is not involved in most of the reported cases but is often unjustly conflated with sexual harassment. What these 100 women argue is that adult women are not, and should not claim to be, defenseless children-lest they lose the ability to enjoy adult sexual relationships.

In France and elsewhere, many people did not like the Le Monde letter (Poirier 2018). It has been suggested that the differences in opinion may be due to a generational gap, with older women being more concerned about sexual freedom and younger women being more concerned about personal autonomy (Collins 2018). Some of the controversy may indeed be due to a more egotistic nature of newer generations (Twenge and Campbell 2010), but replacing sexism with ageism is not productive.

When I was a child half-a-century ago, my mother, who had a chemistry degree, frequently helped me with my school work. She also managed the house as skillfully as a professional property manager. Although my father was the formal breadwinner, I never perceived their occupations to be of unequal worth. When I became a university student, half of my fellow students and half of my professors were women-and, again, I never saw a difference between the worth of men and women as psychology students and psychology professors. If anything, as a heterosexual man, I saw men as valueless when I looked for a romantic partner. It was with great surprise, therefore, that I observed explicit sexism (negative valuation of the opposite sex) after I finished my doctorate and started a postdoctoral fellowship. At the University of Illinois in 1989, I attended a guest presentation by Ingrid Newkirk, president of People for the Ethical Treatment of Animals (PETA). Because I conducted research with animals, I was interested in listening to her, knowing as I did that she opposed animal research. As an open-minded person, I had read Peter Singer's classic book against human exploitation of animals (Singer 1975). It turned out, however, that Newkirk had not been invited by the department of philosophy or by the department of comparative medicine but by the women's studies program. Newkirk realized quickly that her audience was not entirely the audience she was expecting, and she started her presentation by apologizing and explaining that she had prepared the presentation for the women's studies program. But then she went on and insulted and ridiculed men throughout her whole presentation-talking about little else and mentioning animals only when comparing men to dogs and rats. I was astounded. This was the first time in my life that I had witnessed blatant sexism. I knew, of course, that women in my grandmother's generation had had to fight against sexism to gain the right to vote, but that had been 
before I was born. Seeing how the presenter and her intended audience despised men was a very instructive albeit sad experience. It is ironic that, in a recent essay in Time magazine, writer Gillian Flynn wondered whether alleged incidents of sexual misconduct meant that men despise women (Flynn 2017). Throughout my young life never did I wonder whether men and women were substantially different in anything but their sexual anatomy, sexual physiology, and sexual behavior, and I saw no justification for sexism. My experience since then has shown me that some women are very sexist, and Professor Daphne Patai even wrote a book about women's sexism in academia (Patai 1998). These women may claim to be fighting a war against the patriarchy, but, as Martin Luther King warned us, "Hate cannot drive out hate; only love can do that" (King 1963). In other words, sexism will not drive out sexism-and this was the central message conveyed by the 100 French women.

Whether one believes that Catherine Deneuve and the other ninety-nine women were expressing the views of an aging generation that is ignorant of contemporary struggles or that they were bringing much needed wisdom to a not-well-informed younger generation, one thing is certain: that an honest and open discussion of the matter of sexual consent is necessary for societal advancement. Whether or not women want to be "disturbed" by men (the title of this editorial being borrowed from the title of the Le Monde article), serious scholars should certainly want to be disturbed by and engaged with scholars who hold contrary opinions, and Sexuality $\&$ Culture will continue to welcome articles that contribute to this debate.

\section{References}

Chiche, S. et al. (2018). Nous défendons une liberté d'importuner, indispensable à la liberté sexuelle. Le Monde, 8 January 2018.

Collins, L. (2018). Why did Catherine Deneuve and other prominent French women denounce \#MeToo? The New Yorker, 10 January 2018.

Deneuve, C. (2018). Rien dans le texte ne prétend que le harcèlement a du bon, sans quoi je ne l'aurais pas signé. Libération, 15 January 2018.

Flynn, G. (2017). On men. Time, 18 December 2017.

King, M. L., Jr. (1963). Strength to love. New York: Harper \& Row.

Patai, D. (1998). Heterophobia: Sexual harassment and the future of feminism. Lanham, MD: Rowman and Littlefield.

Poirier, A. C. (2018). Catherine Deneuve and the French feminist difference. New York Times, 12 January 2018.

Refinetti, R. (1997). Sexual harassment, sexual consent, and beyond. Sexuality and Culture, 1, 5-17.

Singer, P. (1975). Animal liberation: A new ethics for our treatment of animals. New York: Avon.

Twenge, J. M., \& Campbell, W. K. (2010). The narcissism epidemic: Living in the age of entitlement. New York: Simon \& Schuster.

U.S. Equal Employment Opportunity Commission. (2018). Sexual harassment. https://www.eeoc.gov/ laws/types/sexual_harassment.cfm. 